\title{
Evaluation of socio-spatial vulnerability of citydwellers and analysis of risk perception: industrial and seismic risks in Mulhouse
}

\author{
S. Glatron ${ }^{1}$ and E. Beck ${ }^{1, *}$ \\ ${ }^{1}$ Laboratoire Image et Ville, UMR 7011 Université Louis Pasteur (Strasbourg I), CNRS, France \\ *now at: PACTE-Territoires, UMR 5194 Université Joseph Fourier (Grenoble I), Université Pierre Mendès-France \\ (Grenoble 2), CNRS, France
}

Received: 1 October 2007 - Revised: 9 July 2008 - Accepted: 11 July 2008 - Published: 9 October 2008

\begin{abstract}
Social vulnerability has been studied for years with sociological, psychological and economical approaches. Our proposition focuses on perception and cognitive representations of risks by city dwellers living in a medium size urban area, namely Mulhouse (France). Perception, being part of the social vulnerability and resilience of the society to disasters, influences the potential damage; for example it leads to adequate or inadequate behaviour in the case of an emergency. As geographers, we assume that the spatial relationship to danger or hazard can be an important factor of vulnerability and we feel that the spatial dimension is a challenging question either for better knowledge or for operational reasons (e.g. management of preventive information). We interviewed 491 people, inhabitants and workers, regularly distributed within the urban area to get to know their opinion on hazards and security measures better. We designed and mapped a vulnerability index on the basis of their answers. The results show that the social vulnerability depends on the type of hazard, and that the distance to the source of danger influences the vulnerability, especially for hazards with a precise location (industrial for example). Moreover, the effectiveness of the information campaigns is doubtful, as the people living close to hazardous industries (target of specific preventive information) are surprisingly more vulnerable and less aware of industrial risk.
\end{abstract}

Correspondence to: S. Glatron

(sandrine.glatron@lorraine.u-strasbg.fr)

\section{Introduction}

Risk is a common term, which deserves to be defined more precisely. We consider it as the combination between a potentially damaging phenomenon (hazard, which is characterized by a probability of occurrence, an intensity and a spatial extension) and vulnerability of exposed elements, including people, buildings, activities, environment, etc. (UN-ISDR, 2002). Risk exists only if its two components (hazard and vulnerability) are present. As risk is potential, it is materialized by the occurrence of an event, which causes little damage like an incident, more destructive like a disaster, or, finally, dramatically devastating as would be a catastrophe (Dauphiné, 2001).

Vulnerability is considered to be an important dimension of risk. It is commonly defined as a combination of "exposure and sensitivity to perturbations or external stresses" and "adaptive capacity or resilience" of the vulnerable systems considered (Adger, 2006; Cutter, 2003). Exposure (as measured by economists, ecology experts and geographers) largely depends on the land uses and the density of people, activities or buildings... Density is usually considered as one of the main gradients, especially when taking the spatial dimension into account and when looking for management resources: the more territories are densely occupied, the greater the vulnerability. Describing the spatial distribution of the uses and/or densities - of men, activities, networks and flows - can legitimately be one of the geographers' tasks, as geography deals with a spatial approach. On the other hand, the sociological, political and psychological dimensions of risks, of which importance is not to be stressed in those potential phenomena, are well studied (see Drabeck, 1986; Dynes and Tierney, 1994). The "social response" to disasters are part of the social vulnerability (Thouret and D'Ercole, 1996). They can be linked to various social and demographic general indicators. Policy makers try to anticipate

Published by Copernicus Publications on behalf of the European Geosciences Union. 


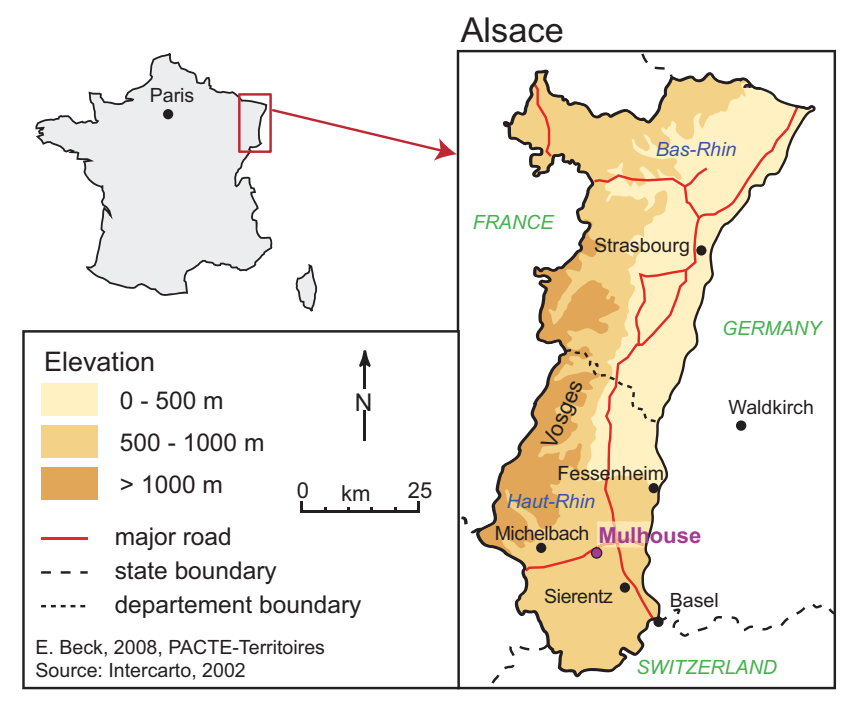

Fig. 1. Geographic location of Mulhouse.

and influence these crisis answers in order to lower the potential consequences of an event. But, presently, the results of these approaches (sociological, political, psychological) are seldom mapped and not pooled into an overall vulnerability index, which could also take into account the spatial dimension of vulnerability. Information about "perception of risk" has been collected for nearly 30 years but has rarely been connected to spatial information in order to be mapped. Geographers have suggested the need to assess social vulnerability for many years (Parker and Harding, 1979), and, more recently, to map multi-criteria vulnerability, generally for natural hazards (Gaillard et al., 2001; Dominey-Howes and Minos-Minopoulos, 2004; Paradise, 2005; Sierra, 2000; Gaillard, 2001). It is in this tradition that we suggest, herein, to explore the psycho-sociological dimension of vulnerability linked to the inhabitants' spatial relationships to dangers or hazards (including the distance). For this purpose, we recently took a survey to study what the inhabitants of the Alsatian urban area of Mulhouse know about major hazards and think about their exposure to those risks. In order to map our observations, we designed a social vulnerability index, which takes account of the way people think about risks.

\section{Surveying city-dwellers and workers on what they know and feel about risks}

\subsection{Mulhouse, a multi-risk urban area}

The urban area of Mulhouse, a medium size city of 172561 inhabitants (INSEE, 1999), is located in Alsace (France) (Fig. 1). It has been affected by various major hazards, both natural and technological. Firstly, for natural hazards, its location in the southern part of the Upper Rhine Graben, near the Jura and the Alps explains tectonic events such as the

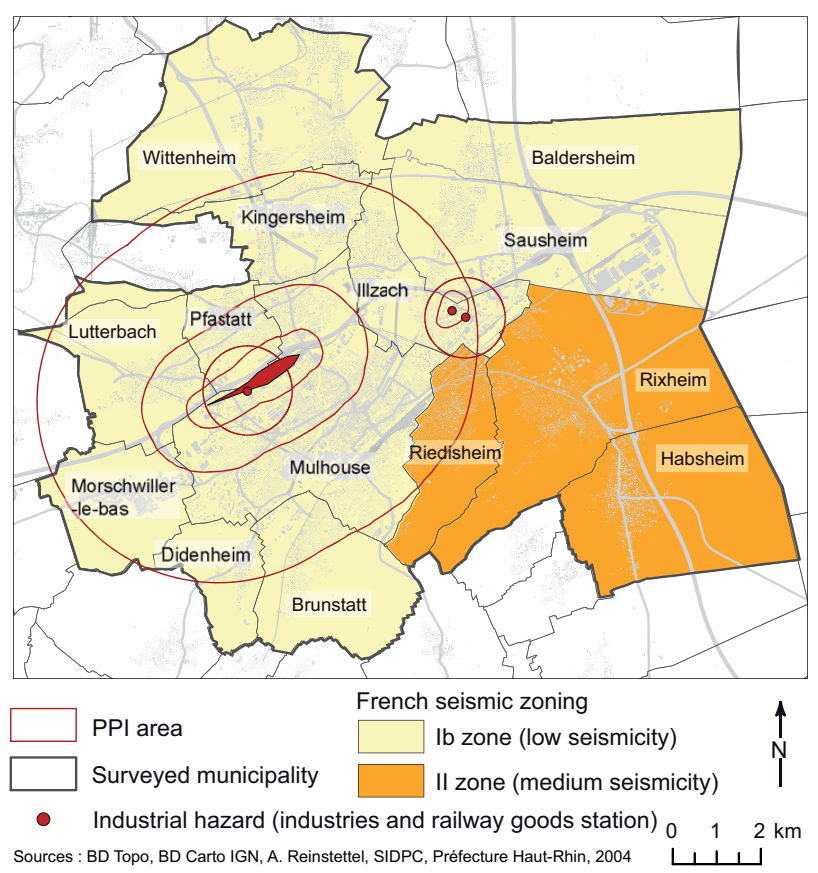

Fig. 2. Seismic and industrial risks in Mulhouse's urban area. The industrial risk is figured by PPI areas within which specific information is delivered. Concerning seismic risk, each municipality is characterized by a zone regarding the French seismic zoning ( 0 , Ia, Ib, II or III). Specific building codes must be applied depending of the zone (zone 1b means less drastic rules than for zone 2) and the type of building (toolshed, house, school, hospital...). No specific information is provided in areas of high or medium seismicity.

terrible Basel earthquake of 1356 (Lambert, 1997). Today, seismic activity is low but nevertheless present (Table 1). In addition, because of the location in a large, flat valley, local towns are regularly flooded by overflowing ground water (Ministère de l'Ecologie, de l'Energie, du Développement Durable et de l'Aménagement du Territoire, 2007). Spring storms often cause muddy flows, and these are also favoured by the intensive corn farming on the Sundgau hills and the relatively loose deposits (loess) (Ministère de l'Ecologie, de l'Energie, du Développement Durable et de l'Aménagement du Territoire, 2007).

Secondly (concerning technological risks), Mulhouse was an important industrial city whose economy was based on the textile and mining industries, especially during the 18th and 19th centuries (Livet and Oberlé, 1977). During the 20th century, chemical and mechanical industries, electrical appliance and plastic production replaced the earlier activities. Thus, there are potentially dangerous plants located within the limits of the urban area including several chemical factories and a petroleum warehouse. Due to the existence of these potentially hazardous plants, the local authorities adopted special prevention plans (Plans particuliers d'intervention, PPI) aimed at ensuring public security (a 
Table 1. Main catastrophic events and incidents experienced in Mulhouse. The macroseismic intensity of an earthquake estimated at the epicentre $\left(\mathrm{I}_{o}\right)$ is described with a Roman numeral on a scale from I to XII (European Macroseismic Scale, EMS98; Grunthal, 2001) and is estimated through the analysis of its impact on people, buildings and other infrastructures, animals and landscape. The magnitude (M) of an earthquake corresponds to the energy emitted at its hypocenter (source on the fault). It is represented by an Arabic numeral on a logarithmic scale (maximum ever recorded: $M=9.5$, Chilean 1970 s earthquake) and is calculated from seismograms.

* Data on earthquakes are delivered by the French national earthquake survey network (Réseau National de Surveillance Sismique, RéNaSS).

\begin{tabular}{|c|c|c|c|c|c|}
\hline Type of event & Date & Location & $\begin{array}{l}\text { Intensity/ } \\
\text { magnitude/ } \\
\text { description }\end{array}$ & Impacts & Source of data* \\
\hline \multirow[t]{5}{*}{ Earthquakes } & $18 / 10 / 1356$ & Basel (Switzerland) & $\mathrm{I}_{o}=\mathrm{IX}-\mathrm{X}$ & $\begin{array}{l}90 \text { castles destroyed } \\
300 \text { killed in Basel }\end{array}$ & $\begin{array}{l}\text { Lambert, 1997; } \\
\text { Meghraoui et } \\
\text { al., } 2001\end{array}$ \\
\hline & $30 / 07 / 1980$ & Sierentz (Haut-Rhin) & $\mathrm{M}=4.8$ & Minor damage & RéNaSS \\
\hline & $22 / 02 / 2003$ & Rambervillers (Vosges) & $\begin{array}{l}\mathrm{M}=5.3 \\
\mathrm{I}_{o}=\mathrm{VII}\end{array}$ & $\begin{array}{l}\text { Many cracks on } \\
\text { buildings, collapsed } \\
\text { chimneys }\end{array}$ & $\begin{array}{l}\text { RéNaSS; BCSF, } \\
2003\end{array}$ \\
\hline & $23 / 02 / 2004$ & Roulans (Doubs) & $\begin{array}{l}\mathrm{M}=5.1 \\
\mathrm{I}_{O}=\mathrm{VI}\end{array}$ & $\begin{array}{l}\text { Power cut, gas leak, } \\
\text { cracks on buildings } \\
\text { and road, collapsed } \\
\text { chimneys }\end{array}$ & $\begin{array}{l}\text { RéNaSS; BCSF, } \\
2004 \mathrm{a}\end{array}$ \\
\hline & $5 / 12 / 2004$ & Waldkirch (Germany) & $\begin{array}{l}\mathrm{M}=5.3 \\
\mathrm{I}_{o}=\mathrm{VI}\end{array}$ & Minor damage in France & $\begin{array}{l}\text { RéNaSS; BCSF, } \\
2004 b\end{array}$ \\
\hline \multirow[t]{4}{*}{$\begin{array}{l}\text { Floods and } \\
\text { muddy flows }\end{array}$} & 27/06/1999 & Mulhouse & & & $\begin{array}{l}\text { Ministère de } \\
\text { l'Ecologie, de } \\
\text { l'Energie, du } \\
\text { Développement } \\
\text { Durable et de } \\
\text { l'Aménagement } \\
\text { du Territoire, } \\
2007\end{array}$ \\
\hline & 25-29/12/1999 & $\begin{array}{l}\text { Baldersheim, Brunstatt, } \\
\text { Didenheim, Habsheim, } \\
\text { Illzach, Kingersheim, } \\
\text { Lutterbach, Morschwiller- } \\
\text { le-Bas, Mulhouse } \\
\text { Pfastatt, Riedisheim, } \\
\text { Rixheim, Sausheim, } \\
\text { Wittenheim }\end{array}$ & & & \\
\hline & $6 / 05 / 2000$ & Kingersheim, Mulhouse & & & \\
\hline & $\begin{array}{l}20 / 06 / 2002 \\
9-11 / 08 / 2007\end{array}$ & $\begin{array}{l}\text { Didenheim, Brunstatt, } \\
\text { Habsheim, Mulhouse, } \\
\text { Riedisheim, Rixheim } \\
\text { Didenheim, }\end{array}$ & & & \\
\hline \multirow[t]{5}{*}{$\begin{array}{l}\text { Industrial } \\
\text { incidents }\end{array}$} & 06/04/1994 & Mulhouse (chemical plant) & $\begin{array}{l}\text { Leak of } 100 \mathrm{~kg} \text { of paran- } \\
\text { itroaniline and of parani- } \\
\text { trochlorobenzene }\end{array}$ & $\begin{array}{l}\text { Two people poisoned, } \\
\text { pollution over a 3-hectare- } \\
\text { surface, } 4 \mathrm{M} \text { of material } \\
\text { damage }\end{array}$ & $\begin{array}{l}\text { Ministère de } \\
\text { l'Ecologie, } \\
\text { de l'Energie, du } \\
\text { Développement } \\
\text { Durable et de } \\
\text { l'Aménagement } \\
\text { du Territoire, } \\
2008\end{array}$ \\
\hline & $08 / 11 / 2001$ & Mulhouse (chemical plant) & $\begin{array}{l}\text { Leak of gaseous } \\
\text { hydrochloric acid }\end{array}$ & One employee injured & \\
\hline & $04 / 10 / 2002$ & Mulhouse (chemical plant) & $\begin{array}{l}\text { Leak of } 50 \mathrm{~kg} \\
\text { of tricholorethylene }\end{array}$ & Pollution of ground water & \\
\hline & 07/07/2003 & Mulhouse (chemical plant) & Explosion & $\begin{array}{l}\text { Two employees injured } \\
\text { (included one seriously) }\end{array}$ & \\
\hline & $07 / 11 / 2006$ & Mulhouse (chemical plant) & $\begin{array}{l}\text { Leak of } 101 \text { of acetyl } \\
\text { chloride }\end{array}$ & $\begin{array}{l}\text { Goods station activity } \\
\text { stopped during } 15 \mathrm{~min}\end{array}$ & \\
\hline
\end{tabular}


Table 1. Continued.

\begin{tabular}{|c|c|c|c|c|c|}
\hline Type of event & Date & Location & $\begin{array}{l}\text { Intensity/ } \\
\text { magnitude/ } \\
\text { description }\end{array}$ & Impacts & Source of data* \\
\hline \multirow[t]{3}{*}{$\begin{array}{l}\text { Transport } \\
\text { accident } \\
\text { implying } \\
\text { hazardous } \\
\text { materials }\end{array}$} & 28/06/1999 & $\begin{array}{l}\text { Mulhouse } \\
\text { (road transport) }\end{array}$ & $\begin{array}{l}\text { Leak of } 45001 \\
\text { of hydrocarbons }\end{array}$ & One person injured & $\begin{array}{l}\text { Ministère de } \\
\text { l'Ecologie, de } \\
\text { l'Energie, du } \\
\text { Développement } \\
\text { Durable et de } \\
\text { l'Aménagement } \\
\text { du Territoire, } \\
2008\end{array}$ \\
\hline & 01/07/1999 & $\begin{array}{l}\text { Mulhouse } \\
\text { (fluvial transport) }\end{array}$ & Leak of oil & Pollution of the basin & \\
\hline & $18 / 06 / 2001$ & $\begin{array}{l}\text { Mulhouse } \\
\text { (transport by train) }\end{array}$ & $\begin{array}{l}\text { Leak of } 100 \text { to } 2001 \\
\text { of hydrochloric acid }\end{array}$ & $\begin{array}{l}\text { Safety zone established } \\
\text { during } 11 \mathrm{~h}\end{array}$ & \\
\hline
\end{tabular}

formal requirement under French and European legislations). Those plans apply to a specific area or zoning (circles, ellipses... Fig. 2), corresponding to the spatial extension of the worst-case scenario of an accident identified by the industrialist. The plan specifies the way a crisis should be managed within this area. Concerning preventive information, the European Seveso 2 Directive requires industrialists to disclose information around the hazardous plants. These information campaigns mainly consist of handing out leaflets to the population. This brochure explains the hazards the population is exposed to, the type of accidents that could occur, the emergency procedures that should be followed in case of an accident, and where people can find further information. Such leaflets had been distributed by industrialists in Mulhouse in 1992 and 2002.

Moreover, with regard to major risks, French legislation requires city mayors to deliver information to the people every two years. This may be achieved via leaflets, organisation of meetings and various advertisement campaigns giving similar information as for industrial risks, but for all the risks the town is exposed to. In the city of Mulhouse, such a leaflet was distributed in April 2004, i.e. just before we started our survey.

Some minor accidents have already occurred (Table 1). For example, in 2002, a leak of trichloroethylene occurred in one of the industrial plants located in Mulhouse. Fortunately it did not have serious consequences for the local population (Ministère de l'Ecologie, de l'Energie, du Développement Durable et de l'Aménagement du Territoire, 2008).

The transport of hazardous materials along road, rail and river networks is also a potential source of danger. The railroad freight station is not considered a "classified" site, but the hazardous materials either stored or in transit represent a high level of risk, according to local authorities (Ministère de l'Aménagement du Territoire et de l'Environnement et al., 2002). For this reason, a PPI has also been defined; its areas have a 500-m radius for the first one and a 4000-m radius for the largest one. This latter concerns 15 municipalities and most of Mulhouse territory (Fig. 2). In addition to these sources of danger located within the city, the Fessenheim nuclear plant and the Michelbach dam are situated $30 \mathrm{~km}$ north and $23 \mathrm{~km}$ west of Mulhouse respectively (Fig. 1).

\subsection{The sample and the questionnaire}

The study is based on data collected during interviews between May 2004 and January 2006. We adopted a multistratified sampling technique, which included the geographical location of the people interviewed, their age, sex and field of work (for the workers). We identified sub-samples, in order to cover most of the population susceptible to frequent the Mulhouse urban area, i.e. residents of the urban area and workers as well. We composed our sample following the quotas sampling method (Berthier, 2000). In this method the sample is proportional to the parent population regarding different criteria: age, sex and town of residence for inhabitants, field of work (education, agriculture, chemical industry, services...) and town of work-place for workers. The parent population was composed of the population counted during the last census in 1999 (Source: INSEE, Institut National de la Statistique et des Etudes Economique (French census adminsitration) and the working population of the urban area (Source: SIRENE, Système d'Identification du Répertoire des Entreprises, French database on companies and establishments). The sample was composed of 491 respondents with the following distribution (Table 2). The distribution regarding sex can be considered similar to the 1999 census (47.0 male and 53.0 female for the sample, $48.2 \%$ of male and $51.6 \%$ of female for the census). Most of the population lives in Mulhouse (60.3\%), which is coherent with the census figures $(56.8 \%)$. Furthermore, the sample is characterized by a high proportion of people with technical certificates (32.8\%), 
Table 2. Composition of the sample interviewed in Mulhouse urban area regarding gender age, municipality of residence, familiy situation and field of work.

* Those two categories are over-represented because we interviewed many working people.

** This classification corresponds to the French nomenclature of activities (Nomenclature des Activités Françaises) established by the French census administration (INSEE).

\begin{tabular}{|c|c|c|c|}
\hline Variable & Composition of sample $(\%)$ & Variable & Composition of sample $(\%)$ \\
\hline Male & 47.0 & Children & 55.8 \\
\hline Female & 53.0 & No children & 44.2 \\
\hline 15-20 years & 9.2 & Single & 32.6 \\
\hline $21-30$ years & 25.9 & In couple & 48.5 \\
\hline $31-40$ years & $20.1^{*}$ & Living with family & 18.9 \\
\hline $41-50$ years & $15.1^{*}$ & Agriculture, hunting, forestry** & 0.4 \\
\hline $51-60$ years & 16.1 & Mining industries & 0.6 \\
\hline$>61$ years & 13.6 & Manufacturing industries & 12.0 \\
\hline Baldersheim & 0.2 & Power, gas and water production and supply & 1.0 \\
\hline Brunstatt & 1.6 & Construction & 2.9 \\
\hline Habsheim & 1.4 & Trade; car and domestic articles repair & 10.2 \\
\hline Illzach & 6.3 & Hotels and restaurants & 3.3 \\
\hline Kingersheim & 3.7 & Transport and communication & 4.1 \\
\hline Lutterbach & 1.8 & Financial activities & 1.6 \\
\hline Morschwiller-le-Bas & 0.6 & Property, renting and services to companies & 6.3 \\
\hline Mulhouse & 60.3 & Public administration & 5.7 \\
\hline Pfastatt & 2.0 & Education & 3.3 \\
\hline Riedisheim & 3.5 & Health and social action & 9.2 \\
\hline Rixheim & 4.9 & Collective, social and personal services & 3.7 \\
\hline Sausheim & 8.8 & Students & 11.6 \\
\hline \multirow[t]{2}{*}{ Wittelsheim } & 4.9 & Other non-working respondents & 4.7 \\
\hline & & No answer given & 19.6 \\
\hline
\end{tabular}

and academic diplomas (32.6\%). $10 \%$ of the respondents are no qualified (no diploma). Concerning the experience of risks, $28.3 \%$ say they have already experienced a disaster and $50.7 \%$ have heard about local incidents or catastrophic events.

The inhabitants were interviewed in the street and the workers at their workplace, the companies having been randomly chosen (simple random sampling (Berthier, 2000) using a table of random numbers and the list of the different companies registered in the French Yellow Pages $®)$.

The questionnaire was composed of 43 closed, semiclosed and open-ended questions and was structured in six parts, each of them exploring a different theme:

1. location of people: this aimed at relating the answers of the surveyed people to their location. It allowed us to integrate the results of the survey into a geographic information system (GIS) and then map the results;

2. perception of risks: first of all, we asked the interviewed people which were the social problems they worried the most. The aim was to compare the importance of ma- jor risks with other problems like pollution, unemployment, wars, etc. Then, we asked what were the hazards they thought they were exposed to. For both these themes, we first used open-ended questions, in order to allow the surveyed person to give spontaneous answers. Several answers were allowed. Then, we repeated the questions by the use of closed questions, in order to suggest answers the person may not have thought of; concerning the terminology, in French, the term "aléa", which can be translated in English as "hazard", is rarely understood by uninitiated persons. Thus, we use the term "risk" in the question. Moreover, the use of "nuisance" is justified by the fact that some phenomena (pollution, smokes...) that we define as risks can be considered as nuisances by laymen;

3. if a disaster were to occur. .. : this part aimed at exploring the prediction capacity of the respondents, which major event he/they thought could happen in Mulhouse, the potential consequences of such a catastrophe, his/her potential reaction and his/her knowledge of the local context (hazard, sources of danger... ). It also 
aimed at questioning the knowledge of safety and alarm procedures;

4. information and risk management: we wanted to know:

- if people felt well informed,

- if they knew the basic risks management principles,

- if they knew who was supposed to inform them,

- if they had received a leaflet on risks,

- who they trusted to inform them,

- by which way they would like to be informed.

This part appeared to be very important to us, as we wanted to have an insight into the level of information of the surveyed population to further pass on this insight to local authorities, so that they could adapt their preventive information campaigns;

1. experience of catastrophes or incidents: one's perception of risk can change depending on one's experience of past disastrous events. Thus, we asked if the surveyed people had experienced any disaster (what type, when...), if any of their relatives had experienced one and if he/she had heard of local catastrophic events or incidents. This also allowed us to identify the level of knowledge of the local context regarding hazards;

2. personal characteristics: the last part aimed at describing the surveyed person in terms of socio-economic characteristics such as age, gender, occupation, field of work, education, type of housing and family situation.

\subsection{Data processing}

Statistical analyses of a survey provide partial information. On the contrary, indexes are likely to give overall information either for each respondent or for geographic zones. In that context, we built a vulnerability index, based on the work of D'Ercole (1996) and Cutter et al. (2000). D'Ercole considers that the socio-spatial vulnerability of people is composed of their physical vulnerability and social vulnerability. According to him, social vulnerability is influenced by several factors that can be gathered in three categories: (1) the perception of risks, (2) the knowledge of risks and of their management - i.e. geography and history of local hazards, preventive information, emergency procedures, and (3) constraining factors like the location of the person, sociodemographic characteristics, etc.

The methodology we developed to build this index is detailed in Beck and Glatron (2006) and Glatron and Beck $(2005,2007)$.

We assigned a value set between 0 and 1 to each survey question answer, depending on its contribution to the vulnerability of the respondent. For example, a good knowledge of emergency procedure corresponded to a value of 0 (low vulnerability) and a person that ignored them would be assigned a value of 1 (high vulnerability). With regard to emergency procedures, a good answer would be "in case of an earthquake, I go under a table" and a poor answer "if an industrial accident occurs, I call my relatives". The final index corresponds to a weighted average of these different values: because we consider that perception and knowledge of risk constitute a large part of vulnerability, we attributed more weight to the corresponding answers.

As geographers, we focus our attention on the spatial dimension of risk perceptions.

Asking our respondents their address of residence or place of work, we were able to locate them and integrate the results into a geographic information system (GIS). Instead of merely representing the results at an individual scale, we chose to aggregate the results at the scale of a defined district, mainly because the information campaigns take place at the scale of a single municipality.

We defined districts according to statistical, administrative and urban morphology criteria and assigned to each resulting district a vulnerability index corresponding to the average of the indexes of the people who are living or working there.

\section{The results}

This paper introduces three ways of presenting results generated by our survey: (1) overall pool results for the whole zone (2); a vulnerability index, which allows us to have an overall view; (3) and a spatial representation of this index, with a results pool at the scale of the districts we will define in $\S 3.3$.

3.1 Pooled results: a limited awareness of major hazards and safety measures

A lot of people think they are safe in the neighbourhood they live in; they do not name any urban nuisance or risk they feel exposed to $(35.4 \%)$. The open-ended question, categorized in Table 3, showed that the people who feel concerned are more worried about the nearby daily nuisances than about major risks. The urban violence is the first item people spontaneously mention: $23.2 \%$ of the respondents cite this problem. The relationships within the neighbourhood worry more than a third of the inhabitants, if we include the nuisance of noise and the worsening of interpersonal relationships that appear in the answers. Consequently, having $35.4 \%$ unconcerned with any problems and another $34.5 \%$ concentrated on neighbourly difficulties, the other problems are overshadowed and spread out, especially the environmental ones. The individual accidents are cited by $33.6 \%$ of the interviewees: road, work, or life (travelling, domestic...) accident and health problems are very present in the people minds. Economic difficulties are not forgotten (employment 
Table 3. The environmental problems Mulhousians feel exposed to.

\begin{tabular}{|c|c|c|}
\hline Type of problem & mentioned risks & $\%$ of respondents \\
\hline \multirow{5}{*}{ relationship } & none & 35.4 \\
\hline & urban violence/insecurity & 23.2 \\
\hline & worsening of interpersonal relationship & 7.0 \\
\hline & noise & 4.3 \\
\hline & road accidents & 12.0 \\
\hline \multirow{2}{*}{ individual accidents } & work accident & 10.0 \\
\hline & Health problems & 5.9 \\
\hline \multirow{4}{*}{ economical worries } & home accident & 5.7 \\
\hline & unemployment & 8.1 \\
\hline & poverty & 4.0 \\
\hline & environmental pollution & 10.2 \\
\hline \multirow{4}{*}{ environment and hazards } & industrial and nuclear risks & 8.1 \\
\hline & natural hazards & 4.9 \\
\hline & other (fire, drug addictions, poverty, terrorism, etc.) & 7.9 \\
\hline & do not know & 1.6 \\
\hline
\end{tabular}

and poverty). Thus, the major environmental problem is pollution $(10.2 \%)$. Nevertheless, major risks appears, being mentioned by $13 \%$ of the sample.

These few worried people can explain why so many of the respondents are not aware of what to do in the case of a disaster, even though the Mulhousians are really exposed to many hazards. Concerning safety measures, more than $60 \%$ of the surveyed people say they do not know the safety procedures $(64.6 \%$ in the case of natural hazard, $63.3 \%$ for industrial accidents; Table 4). Moreover, only $17.3 \%$ or $22.2 \%$ of them give adequate answers, while $10.6 \%$ and $10.2 \%$ answer completely wrongly (for natural and industrial disasters respectively). We assumed this lack of knowledge can badly influence people's vulnerability, as the people's reaction to any event would probably worsen the situation and leads to many victims.

The statistical results give several indications about the way people perceive urban risks, their effects, the methods to be protected and their own risk exposure. But, as we wanted to characterize the vulnerability of people and places, including the role of lay-people's perception in that vulnerability, several factors had to be integrated. That is why we needed an overall index taking into account various parameters we already acquired thanks to the survey and the known localisation of the respondents.

\subsection{The vulnerability index}

Most of our respondents are characterized by a medium vulnerability index score. The average is equal to 0.61 for seismic and industrial indexes (with a standard deviation equal to 0.11 ). As shown in Table 5, the results vary depending on the location of the respondent, especially regarding the official areas of danger and security measures. A low index of vulnerability indicates a good perception of risk. The results show that the people living or working within the PPI have a lower perception of risk than those living outside of the industrial hazard zone, which is astonishing and worrying regarding the efficiency of the information campaigns. If this low perception depend on the information factor, at least partially, we could mention the "denial" effect, in order for people to reduce their anxiety essentially caused by the uncertainty of industrial accident, as shown by Paul Slovic (1986) for example. But we assume that there are many parameters which explain this difference in the perception of the "in" and "out PPI" inhabitants and workers. Thus, the explanation of such a result needs further statistical research and, above all, complementary surveys. In any case, these findings, confirming the importance of distance and location in the public perception of risk lead us to suggest a representation of socio-spatial variability of vulnerability.

\subsection{Cartography of the social vulnerability}

The results show different socio-spatial vulnerability indexes depending on the type of hazard (i.e. industrial or seismic) (Fig. 3).

Regarding seismic hazard, we can notice that there is no spatial pattern in the distribution of the observed values of vulnerability indexes: they seem to be randomly distributed all over the area (Fig. 3a). The vulnerability of the surveyed people does not correlate with municipality boundaries, districts limits or hazard zones. This may be linked to the characteristics of that specific hazard, which is not easily located with precision by lay-people, who do not know the exact location of active seismic faults. This specificity also shows up in risk mitigation. As a matter of fact, unlike industrial risk, which is managed at the industrial plant scale, seismic risk 
Table 4. Distribution of answers about safety procedures in case of natural or industrial catastrophe: "right answer" means that the respondent cited at least one right answer; "mixed answer" means that he/she gave at least one right answer and one wrong answer; "wrong answer" means that only wrong answers were given.

\begin{tabular}{lclll}
\hline Answers (\%) & Safety measures to be followed in case of natural hazard & \multicolumn{4}{l}{ Safety measures in the case of industrial accident } \\
\hline & & Total answers & In PPI & out PPI \\
\hline Adequate answer & 17.3 & 22.2 & 22.6 & 21.0 \\
Mixed answer & 7.5 & 4.3 & 4.0 & 5.0 \\
Unadequate answer & 10.6 & 10.2 & 7.5 & 18.5 \\
Do not know & 64.6 & 63.3 & 65.9 & 55.5 \\
\hline
\end{tabular}

Table 5. Distribution of the index of vulnerability to industrial hazard depending on the place of residence or work of the respondents.

\begin{tabular}{llll}
\hline Values of the index & Out of the PPI & In the PPI & Whole sample \\
\hline $0.29-0.469$ & $32.8 \%$ & $11.6 \%$ & $16.7 \%$ \\
$0.47-0.67$ & $65.5 \%$ & $67.7 \%$ & $67.2 \%$ \\
$0.70-0.82$ & $1.7 \%$ & $20.7 \%$ & $16.1 \%$ \\
Number of people interviewed & 119 & 372 & 491 \\
\hline
\end{tabular}

is mitigated at the scale of the county, which regroups several municipalities (the same building codes apply to a single county).

On the contrary, the "vulnerability to industrial risk index" shows a strong spatial structure, but the results are surprising (Fig. 3b). We observe that most of the districts which are located inside the PPI areas, and which correspond to the districts where the information is delivered, are characterized by a rather high vulnerability, thus a low perception. These observations are illogical, as we would expect the exact opposite results: that the people who live close to a danger source are more prone to be sensitive to the hazard they are exposed to, because most of them see it or sometimes smell it. But this also stresses the matter of preventive information efficiency: we notice that the informed people seem to have an inaccurate perception of risks or at least they do not "perceive" them properly as well as un-officially informed people who live or work outside the measured risk areas (the PPI zones) as outlined by expert of the ministry.

The higher vulnerability of people living within the PPI seems to come partly from a lack of knowledge regarding safety procedures. Figure $4 \mathrm{a}$ shows the proportion of persons (per district) having answered "yes" or "yes, more or less" when asked "do you know the safety procedures you should follow in the case of an industrial accident?" The map shows that the Mulhousians or the people who live within the PPI do no seem to have a better knowledge of the safety procedures than the other city dwellers even if they were informed by the official leaflet distribution in 2002 and 2004 when industrialists and local authorities organised a public information campaign. The adequate or inadequate answers are distributed quite the same way for all city dwellers. The proportion of people who say they are totally unaware of the safety measures for industrial disease are $65.9 \%$ when living in the PPI, and only $55.5 \%$ when living elsewhere in the city (see Table 4 and Fig. 4a). This ignorance or "inadequate knowledge" could increase the degree of vulnerability of the people whenever an accident occurs.

This is corroborated by Fig. $4 \mathrm{~b}$, which shows the proportion of persons (per district) who said they do not feel sufficiently informed about major risks in general. The influence of the information campaigns does not appear on the map; as a matter of fact, we could have expected to find lower proportions of insufficiently informed respondents in districts located within the PPI.

\section{Discussion}

4.1 The limited importance of rare and major events among people's daily worries

Some of our results confirm other scientific findings. Regarding the little importance the population attach to risks, among other problems ( $31 \%$ concerned with urban violence), it is corroborated by other studies. For example, El Jammal and Baumont (2005) showed that 22.3\% of French people consider that unemployment is the most worrying problem, followed by lack of security (17.9\%), and exclusion and poverty (13.6\%). For the IRSN (Nuclear Security and Radioprotection Institute) annual national survey, lack of 

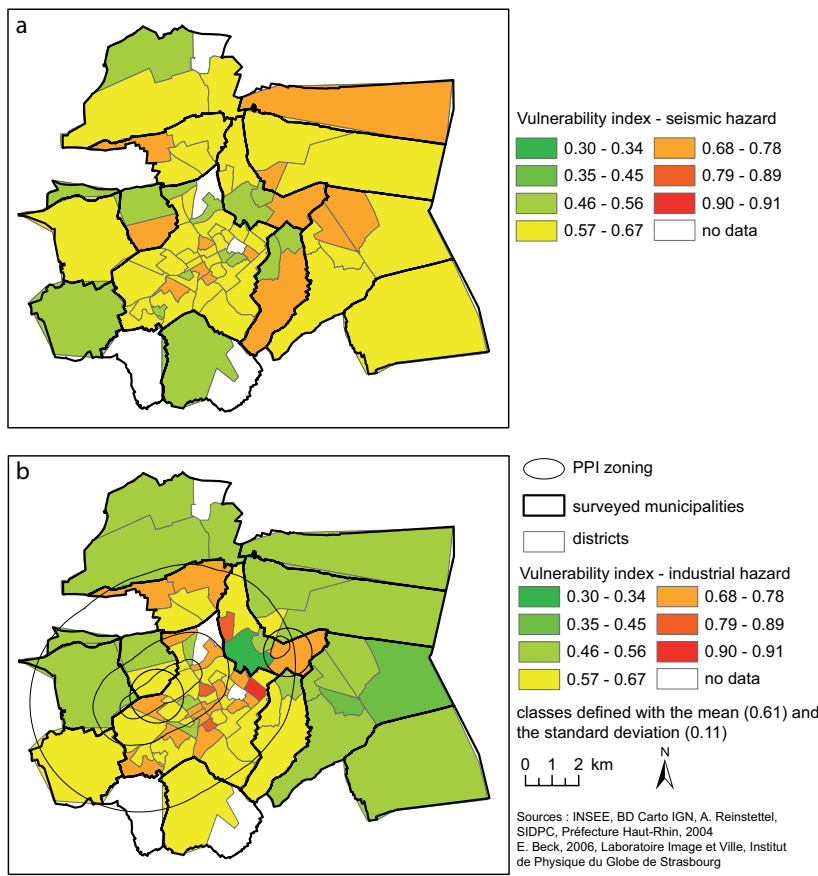

Fig. 3. Vulnerability indexes to (a) earthquakes and (b) industrial risks. For seismic risk (a), there is no relationship between the seismicity and the vulnerability (perception) of the population: municipalities in zone II of the French seismic zoning (cf. Fig. 2) do not seem to be more aware (i.e. less vulnerable) to earthquakes. But the people exposed to industrial hazard (b), i.e. located inside the PPI zoning (cf. Fig. 2) and thus 1) closer to the sources of danger and 2) target of a specific preventive information, are surprisingly more vulnerable (i.e. less aware).

security (formerly urban violence) was ranked at the top in 2001 (37.8\%) and 2002 (24.5\%) (IRSN, 2001; IRSN, 2002, http://www.irsn.org).

For environmental concerns, we again found some similar result trends in the IRSN national survey, where "pollution" was ranked at the top too. But as we asked the open question "What are the social problems you are worried about?" no more than $8.5 \%$ quoted pollution, compared to $18 \%$ for air pollution and $16.2 \%$ for water pollution when people were asked to chose the most important problem within a preestablished list. We do think that pollution is the first environmental concern for Mulhousians, as it refers to "proximity" problems and deals with daily worries. In contrast, less than $5 \%$ quoted industrial and natural risks respectively.

\subsection{The central but difficult role of risks communication}

The issue of the information about risks and communication to people has been debated a lot in the literature since the eighties. Slovic, Lichtenstein, Kasperon and others (see Slovic, 2000) stressed it is a question of importance in the domain of policy-making. The psychometric approach was used to measure factors in the perception and acceptance of
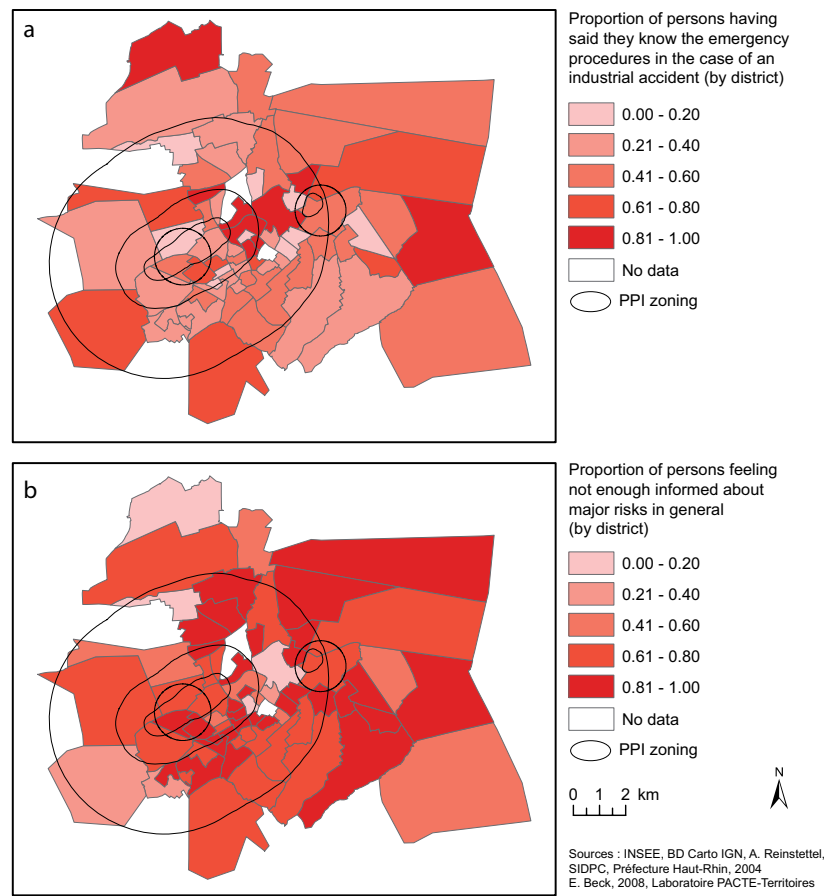

Fig. 4. Proportion of respondents (per district) (a) saying they know the safety procedures in the case of an industrial accident (only $22.2 \%$ actually knew the correct safety measures) and (b) saying they do not feel well enough informed about major risks in general.

risks. Parameters such as people's previous values and beliefs, the familiarity with the phenomena, the threatening degree of risk, the influence of "memorability" of events linked to media reports were isolated. Within this approach, different risks were ranked and people's social and demographic characteristics used to explain preferences. But we could find almost no detailed spatialised results about people's differences of risk perception.

As we observed above, most of the respondents do not know the safety measures; despite being the central message of the leaflets that were distributed. This is of major concern as the knowledge of security procedures is a key point for reducing the vulnerability of the population and the number of casualties when an accident or a catastrophe occurs. Finally, the differences in the results observed between both categories of catastrophes (i.e. natural and industrial) could be explained by the AZF accident. This accident struck the city of Toulouse in 2001, and still sticks in people's minds all over the country, after as the explosion of a warehouse containing ammonium nitrate killed 30 and injured 3000 people (CIEU, 2002). We did not ask directly whether our respondents remembered this event, but 10 of them mentioned it in several answers of the questionnaire, dozens mentioned it freely and, when told about this event to characterize an industrial accident, they all knew what we were talking about. This observation leads to the media's role in communicating 


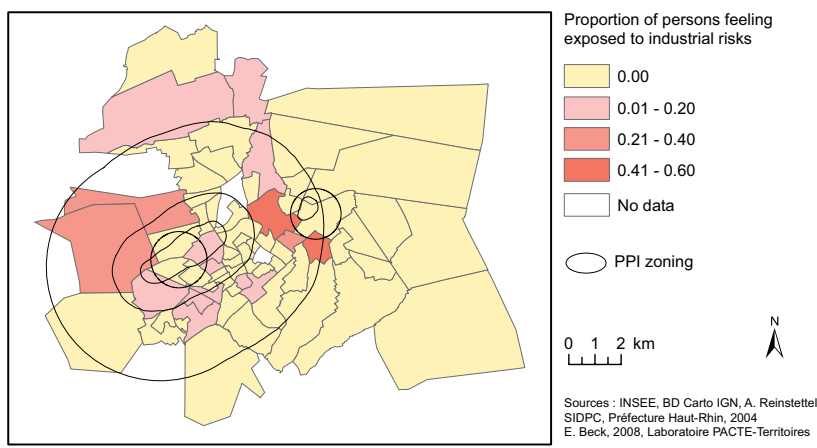

Fig. 5. Proportion of persons (per district) having cited the industrial risk when asked "what are the risks you feel exposed to in this place?" In this map, the districts where no one cited this answer have been isolated on purpose.

risk, which is of major importance and interest but is another research domain (see Slovic, 1986; Wahlberg and Sjöberg, 2000; Wakefield and Elliott, 2003 for example).

\subsection{Distance and perceived risks relationship: a complex function}

The results provided by our survey highlight the problem of the perception of risks with low return period (like seismic risk) or low probability of occurrence (like industrial risk). The spatial component of hazards seems to be of great importance in the risk perception and thus in social vulnerability. Concerning industrial risk perception, the fact that people are more vulnerable (as our index shows (Fig. 3b), when they live close to industrial plants is not only explained by a "low" or "inadequate" perception, i.e. different from an objective risk. Among other things, risk perception can be expressed by the feeling of being exposed to this risk (Slovic, 2000) and we assumed this feeling is also linked to the social and spatial position in the tri-dimensional city, as well as in the imaginary city (but, unlike Bonnet, we didn't test this second hypothesis). Bonnet $(2002,2004)$ suggested mapping the extension of industrial hazards as drawn by lay-people of Le Havre Estuary. The overall perceived risk is mapped but it is not designed the way we suggested, taking into account the three series of factors we described above. Thus, Bonnet doesn't link the "mental maps" to social, demographic and other parameters that could explain the variability of perceptions. Nevertheless, his research proved again that distance to dangerous sources, especially industrial ones, plays a role on the drawing perceived extension of the risky areas, and that the relationship distance-estimation of exposure is not a linear, simple and obvious function as we found too. Lindell and Barnes (1986; Lindell and Earle, 1983) or Chiva (1980) questionned the distance to dangerous plants or their projects (nuclear plants and other technological sources installations in the $\left.80^{\prime}\right)$. But, still, it is proposed as an inconsistent parameter which is not georeferenced, mapped and measured as we suggested to while choosing our respondents with regard to their location in the city: the location of people, their distance to risk and their place in/out of the official security area, though, are our fundamental assumptions and the literature does not say much about this point.

In Mulhouse, few people feel exposed to industrial risk (5.3\% as shown in Table 3). It can be explained by people's non assimilation of the risk nearby. There seems to be a gap between the knowledge of risks and the way people feel exposed to them. We noticed that most of the respondents know the existence of the industrial plants in Mulhouse but they rarely feel exposed to industrial hazard (Fig. 5). This weak integration of the risks existence can be explained by the low probability of occurrence (see Slovic, 2000). Another assumption about this discrepancy comes from the difficulty of people to spatialize hazards due to their ignorance of the spatial extension of hazard. The general form of the information campaigns is here again questioned, as the leaflets generally do not incorporate a risk map. The spatial representation of the risks could help people to better assimilate the risks they are really exposed to. However, further investigations are needed to confirm these assumptions.

Still concerning the distance to risk sources and the relationship with official information, Fig. 5 shows that, even if very few people feel exposed to industrial risk in the whole area, when they live within the PPI area, a higher proportion of respondents cite this industrial hazard when asked "what are the risk you think you are exposed to in this place?" This is an important finding, because other authors, like Bonnet (2002), found unexpected results regarding the relationship between industrial risk perception and distance. He concluded, as Slovic had before $(1986,2000)$ that the proximity to an industrial plant could create a feeling of denial: the closer interviewed persons live or work to an industrial plant, the more likely they were to reject the actual risk.

In fact, the last point (proximity creates higher perception or, on the contrary, denial) depends much on the type of risk. The vulnerability, whether physical, material or sociopsychological, greatly depends on the hazard. We found its spatial distribution is very different for seismic or industrial risk. This simultaneous study of various risks, in the same territorial units, in order to be able to compare the vulnerability indexes, is our contribution to D'Ercole's approach (1996). Meanwhile, our territorial units must be discussed as it is hard to take into account various sources and effects of risks and to integrate all the useful characteristics of the basic district used for analysis and cartography like in Thouret and D'Ercole research (1996), where they partitioned the risk basin with regards to the type of consequences, the risk intensity, the administrative limits, the population density and the urban form. 


\subsection{Some problems to be solved and paths to be explored}

The methodology which was introduced in this paper raises a few questions.

Concerning the construction of the index, it is doubtful that the average of the different values is the most relevant index: using the average, despite its statistical inadequacy, gives a general trend of the results but can also hide the heterogeneity of the results.

Moreover, the question of the weighting of the answers is not yet clearly resolved. How might it be validated?

Concerning the pooling of the findings, we must outline several points. First, the link between individual answers and spatial cartography of the medium ratio answers raises methodological questions: how can individual views be generalized to collective ones? We assumed that the dominant socio-demographic characteristics included in homogeneous urban districts would be an acceptable basis for the sociospatial dominant representation of risks. Second, there is a small discordance between our survey sampling, based on the municipalities which are statistical units, and the districts which are our cartographic basic units and correspond to a division of the municipalities. Thus, some of them are over-sampled and others under-sampled. The results can be considered representative for the districts where many interviewed people live or work, but not for the less dense ones. This highlights a weakness linked to the lack of data in the under-sampled districts, where additional surveys should be conducted. We must still improve the method and think about which spatial divisions could be more relevant. On one hand, we need a spatial unit linked with statistical data. It should have urban and socio-economic homogeneity. On the other hand, the zone where preventive information is delivered needs to be integrated too (as information is part of the knowledge component and is likely to influence vulnerability).

Another important question deals with the temporal extension of the survey, as we know "affective" factors may widely influence the perception of risks. For example, the occurrence of a disaster, reported by the media will affect the "memorability" of past event and the "imaginability of future" events, as shown, for example by Slovic, 1986. Consequently, it is worthwhile asking the questionnaire in as short a time as possible. For material reasons, we could not do so. Fortunately, no major incident, whether local or national, seemed to be able to change people's perception during the several months of our survey.

Finally, as we found that the type of hazard (i.e. industrial or seismic) influences the socio-spatial vulnerability, we would probably find other values for other types of risks (flood, nuclear, transport of dangerous goods). Complementary surveys could help to implement this hypothesis too and lead to the "multi-risk" approach we are aiming to develop.

\section{Conclusions}

In Fig. 5 we showed that risk perception depends on the type of hazard considered by the respondent. Seismic risk perception is rather explained by sociological factors than by spatial factors, due to the inconsistent location of its source.

We would like to integrate this partial psychosocial vulnerability index into a more general socio-spatial vulnerability index, which would take into account the physical and functional aspects as well as the socio-economical aspects. As a perspective, it remains so be seen whether the impact of preventive information will be efficient in saving lives and goods in the case of an emergency.

What we present here, unfortunately, can only claim to be a small aspect of "the challenges for vulnerability research [...] to develop robust and credible measures, to incorporate governance research on the mechanisms that mediate vulnerability and promote adaptative action and resilience" (Adger, 2006). In fact, as shown by Borraz et al. (2005) in our French context, institutional vulnerability was a forgotten subject within the very active and multidisciplinary research domain around major risks and hazards over the last thirty years.

Edited by: M. Keiler, S. Fuchs, and T. Glade

Reviewed by: Dale Dominey-Howes and two other anonymous referees

\section{References}

Adger, W. N.: Vulnerability, Global Environmental Change, 16(3), 268-281, 2006.

Beck, E. and Glatron, S.: La vulnérabilité socio-spatiale des citadins aux risques majeurs. Risques industriels et risque sismique dans l'agglomération de Mulhouse, in : Proceedings of SAGEO 2006, Colloque International de Géomatique et d'Analyse Spatiale. Recherches \& Développements, Strasbourg, France, 11-13 Septembre 2006, 12 pp., 2006.

Berthier, N.: Les techniques d'enquête. Méthode et exercices corrigés. A. Colin, Cursus, Paris, 254 pp., 2000

BCSF (Bureau Central Sismologique Français): Séisme de Rambervillers (dép. 88) du 22 février 2003. Observations macrosismiques, Preliminary report, 14 pp., 2003.

BCSF (Bureau Central Sismologique Français): Séisme de Roulans (dép. 25) du 23 février 2004, Preliminary report, 21 pp., 2004a.

BCSF (Bureau Central Sismologique Français): Rapport sur le séisme du 5 décembre 2004 de Waldkirch (Allemagne) Magnitude 4.9 Ml, Report, 35 pp., 2004b.

Bonnet, E.: Risques industriels: évaluation des vulnérabilités territoriales. Le cas de l'estuaire de la Seine. PhD thesis, Université du Havre, France, 331 pp., 2002.

Bonnet, E.: Risques industriels: territoires vulnérables de l'estuaire de la Seine, Mappemonde, 76(4), 1-6, (http://mappemonde. mgm.fr/num4/articles/art04401.html), 2004.

Borraz, O., Gilbert, C., and Joly, P.-B.: Risques, crises et incertitudes: pour une analyse critique (Vol. 3). Maison des sciences de l'homme-Alpes, 2005. 
CIEU: L'explosion de l'usine AZF à Toulouse: une catastrophe inscrite dans la ville, Mappemonde, 65(1), 23-28, 2002.

Chiva, I.: Perception du risque autour de quelques centrales nucléaire, Proceedings of the Colloque de la Fédération française de l'énergie nucléaire, Paris, janvier 1980, 176-193, 1980.

Cutter, S. L., Mitchell, J. T., and Scott, S. M.: Revealing the vulnerability of people and places: a case study of Georgetown County, South Carolina, Annals of the Association of American Geographers, 90(4), 713-737, 2000.

Cutter, S. L.: The Vulnerability of Science and the Science of Vulnerability, Association of American Geographers, 93(1), 1-12, 2003.

Dauphiné, A.: Risques et catastrophes. Observer, spatialiser, comprendre, gérer, Armand Colin (Eds.), 288 p., 2001.

D'Ercole, R.: Représentations cartographiques des facteurs de vulnérabilité des populations exposées à une menace volcanique. Application à la région du volcan Cotopaxi (Equateur), Bull. Inst. Etudes andines, 25(3), 479-507, 1996.

Dominey-Howes, D. and Minos-Minopoulos, D.: Perceptions of hazard and risk on Santorini, Journal of Volcanology and Geothermal Research, 137, 285-310, 2004.

Drabeck, T. E.: Human system response to disaster: an inventory of sociological findings, New York: Springer-Verlag, 1986.

Dynes, R. R. and Tierney, K. J.: Disasters, collective behavior and social organization, Crambury, New Jersey: Associated University Presses, 1994.

El Jammal, M.-H. and Baumont, G.: Perception des risques et de la sécurité. Résultats du sondage d'octobre 2004, Note DSDRE/UGR 05/03, Institut de Radioprotection et de Sûreté Nucléaire, Unité de gestion des risques, Direction de la Stratégie, du Développement et des Relations Extérieures, 74 pp., 2005.

Gaillard, J.-C.: Implications territoriales et socio-économiques des crises et des réponses liées à l'éruption et aux lahars du Mont Pinatubo, 1991-2001 (Philippines), PhD thesis, Université de Savoie, France, 378 pp., 2001.

Gaillard, J.-C., D'Ercole, R., and Leone, F.: Cartography of Population Vulnerability to Volcanic Hazards and Lahars of Mt. Pinatubo (Philippines): Case of Pasig-Potrero River Basin (Province of Pampanga), Géomorphologie: relief, processus, environnement, 3/2001, 209-222, 2001.

Glatron, S. and Beck, E.: Discontinuités dans les représentations des risques majeurs par les citadins. Perception des risques par les habitants et les actifs de l'agglomération de Mulhouse. In : Catastrophes, discontinuités, ruptures, limites, frontières. Comment les analyser ? Comment les anticiper? Proceedings of the 44èmes journées de Rochebrune, Rencontres interdisciplinaires sur les systèmes complexes naturels et artificiels, Rochebrune, Megève, France, January 2007, 55-67, 2007.

Glatron, S. and Beck, E.: Prévention des risques majeurs dans l'agglomération mulhousienne : quelles perceptions et quels points de vue des actions? Les cahiers de l'IAURIF, 142, 105$117,2005$.

Grünthal, G.: L'Echelle Macrosismique Européenne - European Macroseismic Scale 1998, Cahiers du Centre Européen de Géodynamique et de Séismologie, vol. 19, Ministère de la Culture, de l'Enseignement Supérieur et de la Recherche du Luxembourg, Conseil de l'Europe, 103 pp., 2001.
IRSN: Perception des risques et de la sécurité, résultats du sondage de novembre 2002. IRSN, p. 107, 2002.

IRSN: Perception des risques et de la sécurité, résultats du sondage de novembre 2002. IRSN, p. 90, 2001.

Lambert, J.: Les tremblements de terre en France, hier, aujourd'hui, demain, BRGM, 196 pp., 1997.

Lindell, M. and Barnes, V. E.: Protective response to technological emergency: risk perception and behavioural intention, Nuclear Safety, 27(4), 457-467, 1986.

Lindell, M. and Earle, T. C.: How close is close enough: Public perceptions of the risks of industrial facilities, Risk Analysis, 3(4), 245-253, 1983.

Livet, G. and Oberlé, R.: Histoire de Mulhouse des origines à nos jours, Editions des Dernières Nouvelles d'Alsace, ISTRA, 493 pp., 1977.

Meghraoui, M., Delouis, B., Ferry, M., Giardini, D., Huggenberger, P., Spottke, I., and Granet M.: Active normal faulting in the Upper Rhine Graben and Paleoseismic Identification of the 1356 Basel Earthquake, Science, 293, 2070-2073, 2001.

Ministère de l'Aménagement du Territoire et de l'Environnement, Préfecture du Haut-Rhin and Mairie de Mulhouse: Document Communal Synthétique de la Ville de Mulhouse, 2002.

Ministère de l'Ecologie, de l'Energie, du Développement Durable et de l'Aménagement du Territoire: Prévention des risques majeurs, Ma commune face aux risques majeurs : arrêtés de catastrophe naturelle. http://www.prim.net/cgi_bin/citoyen/ macommune/23_face_au_risque.html. Last update: July 2007.

Ministère de l'Ecologie, de l'Energie, du Développement Durable et de l'Aménagement du Territoire: Base ARIA du Bureau d'Analyse des Risques et Pollutions Industrielles: http://www. aria.developpement-durable.gouv.fr/. Last update: 12 June 2008.

Paradise, T. R.: Perception of earthquake risk in Agadir, Morocco: a case study from a muslim community, Environ. Hazards, 6(3), 167-180, 2005.

Parker, D. J. and Harding, D. M.: Natural hazard evaluation, perception and adjustment, Geography, 64(4), 307-316, 1979.

Sierra A.: Gestion des enjeux des espaces urbains à risques d'origine naturelle. Les versants et les quebradas de Quito, Equateur. $\mathrm{PhD}$ thesis, Centre de recherche en Analyses géopolitiques, Université de Paris 8, France, 326 pp., 2000.

Slovic, P.: Informing and Educating the Public about Risk, Risk Analysis, 6(4), 403-415, 1986.

Slovic, P.: The perception of risk, Earthscan Publications Ltd. Risk, Society and Policy Series, 473 pp., 2000.

Thouret, J.-C. and D'Ercole, R: Vulnérabilité aux risques naturels en milieu urbain: effets, facteurs et réponses sociales, Cahiers des sciences humaines, 32(2), 407-422, 1996.

UN-ISDR (United Nations - International Strategy for Disaster Reduction): Living with risk. A global review of disaster reduction initiatives, United Nations report, 382 pp., 2002

Wahlberg, A. and Sjöberg, L.: Risk perception and the media. A review of research on media influence on public risk perception, Journal of Risk Research, 3, 31-50, 2000.

Wakefield, S. E. L. and Elliott, S. J.: Constructing the news: The role of local newspapers in environmental risk communication, The Professional Geographer, 55, 216-26, 2003. 